\title{
STUDENT FINAL GRADING METHOD FOR INFORMATICS AND COMPUTER ARCHITECTURE
}

\author{
Alexander Kuzmin \\ Peter the Great Saint-Petersburg Polytechnic University, Russia \\ kuzmalexander@yandex.ru
}

\begin{abstract}
To achieve the requirements of modern education standards not only the lecture and practice delivering process must be updated, but the final grading method is to be improved as well. The common practice during an examination is to ask a student to provide a smooth oral exposition of one or more relatively large pieces of content, covering some of the course topics. In this case, it is difficult to provide a totally objective and unbiased evaluation of student's knowledge. Actually, this problem is solved now individually be each lecturer using his professional skills and experience to pose additional questions involving a student into a topic-oriented discussion, thus making a judgement about the student's knowledge and competency level. At first sight, the list of course textbook questions and exercises may be applicable for the purpose of final examination, but this immediate solution is not appropriate, because each textbook question is aimed to stimulate students to read and realize carefully a certain part of text; therefore, answering textbook questions does not basically reveal the entire student competency. Being specially adopted for examination needs the textbook questions can be a powerful means of student competency check. A method to create series of brief discriminative questions on particular pieces of the course content is proposed to make the final grading of students clear and objective. A number of annotated sample questions for informatics and computer architecture are provided.
\end{abstract}

Keywords: engineering education, grading, computer architecture, informatics.

\section{Introduction}

The modern approach of engineering educational curricula requires not only to update the means of education but also to improve the grading procedures as well as student evaluation criteria [1-3]. The main trends in modern engineering pedagogy tackle student active involvement in the process of learning [4]. Repetition-based learning is now viewed as incompatible with the responsibilities of engineers and IT-professionals, because they need not only to read specifications competently, but also to analyze and understand their work and its implications. It is clear that repetition, the key strategy of the traditional learning paradigm, is not enough. Piaget [5] and Vygotsky [6] among the founders of contemporary approaches to learning introduced novel approaches in opposition to the traditional paradigm. They regard students as active, autonomous, willing to construct knowledge from their own experience. The learning process is not successful, if the students passively repeat what the instructor tells them to do [7]. Engineering students are typically more engaged and persistent than students of other majors [8;9], so the experimental approach described can lead to a significant increase of academic performance especially in engineering disciplines [10; 11].

Basically, student evaluation through oral examination suggests a continuous exposition of a piece of course matter (course fragment) presented by a student. During the examination the teacher faces a number of doubts and problems concerning the two following questions:

- Depth of understanding of basic concepts and terms

- Integrity issues and student respect to the code of ethics.

These problems are empirically solved through teacher's experience and proficiency to make the examination process more interactive. Some additional questions are posed to a student, some points are proposed to discuss in detail. All these lead to a necessity of making a method to create brief and concise questions, which can help reveal the level of student competency in an objective and unbiased manner.

Making such questionnaires seems to be straightforward due to the fact that the majority of textbooks contain sections of exercises and controlling questions. But taking these questions to the exam "as is" is hardly appropriate as they focus on motivating students to read thoroughly rather than to check their knowledge. Being properly updated and reorganized, textbook questions can be helpful to evaluate the students. 
Being applicable for any engineering discipline, the approach to create examination question sets is adapted for informatics and computer architecture course. These question sets are aimed at motivating students to thorough study of the subject as well as provide an objective evaluation tool.

This article faces the problem of objective student grading, which is planted in a number of specifically organized semester-long activities: testing, essay writing and peer-reviewing. Essay writing and peer reviewing form a basis for critical thinking and active attitude towards learning the subject.

\section{Materials and methods}

The methodology to create examination question sets originates from 4 basic principles.

- Questions are to be focused on the most important definitions and terms;

- Comparisons and associative links between terms can be used;

- Maximum effectiveness, which includes performance, implementation overhead, sustainability, stability, energy saving, etc., is a primary goal for computer hardware design and this fact must be repeatedly highlighted.

- Questions in a form of a paradox can be used to keep students' interest and attention focused on a subject as well as boost student ability for reasoning.

All these points are aimed to construct examination question sets with all possible creativity.

Students preparing to the final grading starts at the beginning of the semester and evolves successively.

The proposed method includes six activities to complete in the course of the semester (semester activities) and the last one is merely the final examination done by the end of the semester. All activities give students a number of credits to earn (Table 1) and have an impact for final grade.

1. Testing.

A focus group is offered an incoming test to monitor their basic knowledge of informatics. It is supposed that students already have some background from their secondary school and one or two high school courses on informatics. The purpose of this test is to adapt the course material to an actual level of the group.

2. Essay.

Students write short (1-2 pages) essays on history of computing. This work stimulates student interest to the subject and reveals scientific ideas development in historical context.

3. Reviewing.

Reviewing criteria are discussed and elaborated. Peer reviewing and evaluation invoke knowledge transfer between students.

4. Longer essays.

5. 4 written tests.

6. Early examination (optional).

7. Regular examination.

Activity credits available for students in the course of a semester

Table1

\begin{tabular}{|c|c|}
\hline Semester activity & Maximum number of credits \\
\hline Testing & 2 \\
\hline Essay & 2 \\
\hline Reviewing & 2 \\
\hline Longer essays & 3 \\
\hline 4 written tests & 2 each \\
\hline Total for semester activities & 17 \\
\hline $\begin{array}{c}\text { Examination, either rehearsal or regular } \\
\text { (15 short questions) }\end{array}$ & 15 \\
\hline
\end{tabular}


Each semester activity gives a student a number of credits (17 credits at maximum). Those, who have 14 credits and more, get their maximum final grades (" 5 "/excellent) without examination. Others, who have more than 8 credits, get 1 additional point to their examination result.

Final grading is based on examination question sets. Students are offered to write answers to 15 short questions within 45 minutes. Questions are taken from the examination set (Table 2 shows some sample questions). Examination is done under the following conditions:

- "Open book" form makes examination less stressful and helps for better creativity

- No multiple or single choice questions, so guessing is impossible.

Final examination gives students 1 credit for each correct answer, thus, a student gets from 0 to 15 primary credits. The scale of mapping these credits into exam marks is: $>10-$ " $5 " ;>8-44 " ;>6$ - " 3 "; 5 and less credits mean that the exam is not passed successfully.

\section{Results and discussion}

The proposed method was put into practice in 2010. The main outcome is more extensive course content coverage. Until 2010, a regular exam covered 69 topics, each student got only 2 questions, thus, a share of course content covered by the student answer was approximately $3 \%$. Since 2010 , when the proposed method was introduced, a number of questions grew to 15 (Table 2), as well as semester activities were applied. Thus, the coverage share grew up to $40 \%$ (20\% due to exam and $20 \%$ due to the written tests).

Table 2

Examination set samples

\begin{tabular}{|c|c|c|}
\hline Question & Possible answer & Comments \\
\hline $\begin{array}{l}\text { What is the main } \\
\text { drawback of "sign- } \\
\text { and magnitude" } \\
\text { representation? }\end{array}$ & $\begin{array}{l}\text { The problem of representing a number's } \\
\text { sign can be to allocate one sign bit to } \\
\text { represent the sign: setting that bit to } 0 \text { is for } \\
\text { a positive number or positive zero, and } \\
\text { setting it to } 1 \text { is for a negative number or } \\
\text { negative zero. It leads to a performance lost } \\
\text { due to the number of operation increase. }\end{array}$ & $\begin{array}{l}\text { In this case, subtraction is } \\
\text { done in two steps: } \\
\text { comparison and operation } \\
\text { itself, while using of one's } \\
\text { or two's complement } \\
\text { evades the comparison. } \\
\text { Ones' complement allows } \\
\text { for simpler hardware } \\
\text { designs as there is no need } \\
\text { to convert values when } \\
\text { passed to and from the math } \\
\text { unit. Moreover, two's } \\
\text { complement is the easiest to } \\
\text { implement in hardware. }\end{array}$ \\
\hline $\begin{array}{l}\text { Describe a model } \\
\text { for an information } \\
\text { unit (a bit) }\end{array}$ & $\begin{array}{l}\text { Coin flipping illustrates Shannon definition } \\
\text { based on entropy }\end{array}$ & $\begin{array}{l}\text { A fair coin has two sides - } \\
\text { picture one side with a } 0 \\
\text { (zero), and the other side a1 } \\
\text { (one). The only possible } \\
\text { results of tossing this coin } \\
\text { are to see either the } 0 \text { or the } \\
1 \text { side. That information - } \\
\text { which of the two sides that } \\
\text { came up at the coin toss - } \\
\text { can be stored in one data bit }\end{array}$ \\
\hline $\begin{array}{l}\text { What was the } \\
\text { purpose of Turing } \\
\text { machine invention? }\end{array}$ & $\begin{array}{l}\text { Turing machine was not invented } \\
\text { deliberately and is not a device. It is a } \\
\text { computational abstraction to evaluate } \\
\text { algorithmic complexity. }\end{array}$ & $\begin{array}{l}\text { An example of a paradox- } \\
\text { like question to involve a } \\
\text { student to a discussion. }\end{array}$ \\
\hline
\end{tabular}


Table 2 (continued)

\begin{tabular}{|c|c|c|}
\hline Ouestion & Possible answer & Comments \\
\hline $\begin{array}{l}\text { What is the } \\
\text { difference between } \\
\text { functional } \\
\text { specification and a } \\
\text { block diagram? } \\
\text { Give your } \\
\text { explanation for a } \\
\text { memory unit. }\end{array}$ & $\begin{array}{l}\text { Functional specification describes the } \\
\text { purpose of a device. Block diagram } \\
\text { discloses its architecture. }\end{array}$ & $\begin{array}{l}\text { Functional specification } \\
\text { typically describes what is } \\
\text { needed by the system user } \\
\text { as well as requested } \\
\text { properties of inputs and } \\
\text { outputs, whereas block } \\
\text { diagrams are typically used } \\
\text { for higher level, less } \\
\text { detailed descriptions that } \\
\text { are intended to clarify } \\
\text { overall concepts without } \\
\text { concern for the details of } \\
\text { implementation. }\end{array}$ \\
\hline $\begin{array}{l}\text { Why modern } \\
\text { general purpose } \\
\text { microprocessors do } \\
\text { not have duplicate } \\
\text { and reverse } \\
\text { operations? }\end{array}$ & $\begin{array}{l}\text { Because they do not affect the performance } \\
\text { significantly. }\end{array}$ & $\begin{array}{l}\text { These commands improve } \\
\text { memory access functions } \\
\text { when cash memory is used, } \\
\text { but close examination } \\
\text { showed that for a hardware } \\
\text { stack RAM there is no } \\
\text { evident benefit. }\end{array}$ \\
\hline $\begin{array}{l}\text { Name some of } \\
\text { specific machine } \\
\text { commands executed } \\
\text { in ALU }\end{array}$ & Binary arithmetic, shifts, etc. & $\begin{array}{l}\text { In a latent form the student } \\
\text { is offered to think about } \\
\text { human and computer } \\
\text { reasoning. }\end{array}$ \\
\hline $\begin{array}{l}\text { Why instruction } \\
\text { pipelining is less } \\
\text { reliable than } \\
\text { parallel computing? }\end{array}$ & $\begin{array}{l}\text { Instruction pipelining is a technique for } \\
\text { implementing instruction-level parallelism } \\
\text { within a single processor. Parallel } \\
\text { processing and pipelining techniques are } \\
\text { duals of each other: if a computation can be } \\
\text { pipelined, it can also be processed in } \\
\text { parallel. Both of them exploit concurrency } \\
\text { available in the computation in different } \\
\text { ways. }\end{array}$ & $\begin{array}{l}\text { Pipelining attempts to keep } \\
\text { every part of the processor } \\
\text { busy with some instruction } \\
\text { by dividing incoming } \\
\text { instructions into a series of } \\
\text { sequential steps performed } \\
\text { by processor units with } \\
\text { different parts of } \\
\text { instructions processed in } \\
\text { parallel. It allows } \\
\text { faster CPU throughput than } \\
\text { would otherwise be possible } \\
\text { at a given clock rate, but } \\
\text { may increase latency due to } \\
\text { the added overhead of the } \\
\text { pipelining process itself. }\end{array}$ \\
\hline
\end{tabular}

In 2016 and 2017 a retrospective analysis was performed. Students, who have been already evaluated using this method, were asked to give feedback. They classified and commented on 109 questions from an examination set. $58(53.2 \%)$ questions were deemed as "simple and basic"; 36 (33\%) were deemed as "of moderate complexity and basic"; 15 (13.8\%) were supposed to be complicated. 17 questions from all these three groups were said to be vague and not formulated explicitly. This feedback resulted in further updates of the question sets. 
For 8 last years (since 2010 to 2018) the author can observe a stable growth of mean exam mark that reached $30 \%$ in 2017 in comparison to 2015. Statistics of marks is given in Fig. 1. A share of "good" marks grows progressively, that can be viewed as a positive outcome of the method applied.

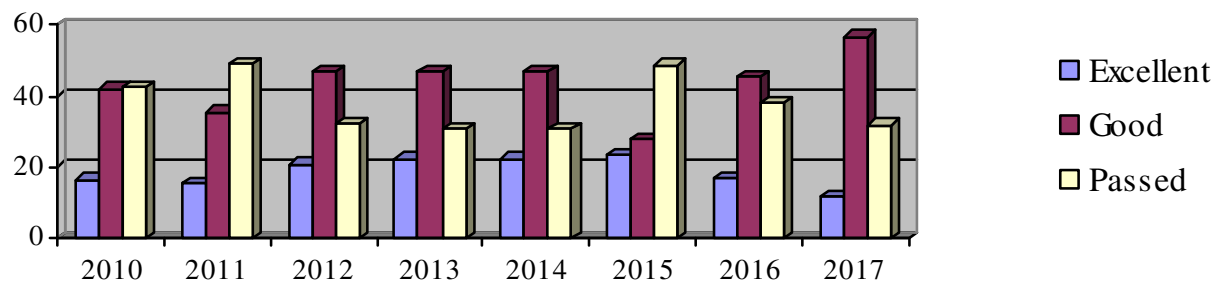

Fig. 1. Mark breakdown

\section{Conclusions}

1. The method to grade students for any engineering discipline is presented. This method increases course coverage during the exam from 3 to $40 \%$. Thus, student evaluation becomes more objective.

2. Four elaboration principles of the proposed method are introduced. Examples of questions are given.

3. Semester activities are described.

4. As the result, students keep being focused on the subject during the whole semester.

5. Different activities are switched, thus, classroom work is less tedious.

6. Final examination questions created in accordance with the proposed method provoke critical thinking and knowledge transfer.

7. All the examination procedure gets less stressful and summarizes the course material.

8. In general, a better level of academic performance was achieved and positive feedback from students was obtained.

\section{References}

[1] Yigit T. et al. Evaluation of blended learning approach in computer engineering education //Procedia-Social and Behavioral Sciences. vol. 141, 2014, pp. 807-812.

[2] Linck B. et al. Competence model for informatics modelling and system comprehension //Global Engineering Education Conference (EDUCON), IEEE, 2013, pp. 85-93.

[3] Dym C. L. et al. Engineering design thinking, teaching, and learning //Journal of Engineering Education. vol. 94, №. 1, 2005, pp. 103-120.

[4] Case J. M., Light G. Emerging research methodologies in engineering education research //Journal of Engineering Education. vol. 100, № 1, 2011, pp. 186-210.

[5] Piaget, J. The Psychology of Intelligence, First edition. Routledge, 2001.

[6] Vygotsky, L. S. Mind in Society: The Development of Higher Psychological Processes. Harvard University Press, Cambridge, MA, 1978.

[7] Kern V. M., Saraiva L. M., dos Santos Pacheco R. C. Peer review in education: promoting collaboration, written expression, critical thinking, and professional responsibility //Education and Information Technologies. vol. 8, №. 1, 2003, pp. 37-46.

[8] Matusovich H. M., Streveler R. A., Miller R. L. Why do students choose engineering? A qualitative, longitudinal investigation of students' motivational values //Journal of Engineering Education. vol. 99, №. 4, 2010, pp. 289-303.

[9] Krivickas R. V., Krivickas J. Laboratory instruction in engineering education //Global J. Eng. Educ. vol. 11, №. 2, 2007, pp. 191-196.

[10] Ohland M. W. et al. Persistence, engagement, and migration in engineering programs //Journal of Engineering Education. vol. 97, №. 3, 2008, pp. 259-278.

[11]Baron G. L., Bruillard E. Information technology, informatics and pre-service teacher training //Journal of computer assisted learning. vol. 10, №. 1, 1994, pp. 2-13. 